riverine areas : they not only keep open the channels by their traffic but also keep the waters well fertilized with their dung. It is by no means a coincidence that good hippo areas are also good fishing areas.

\title{
THE WILD LIFE SITUATION IN SOUTHERN RHODESIA, I952
}

\author{
By I. D. M.
}

It is sad to have to report that the game in Southern Rhodesia is fast disappearing and if the Government's present policy continues for much longer, it will be exterminated except in a few areas. In the past, this has happened in the Union of South Africa and now it is to repeat itself north of the Limpopo.

Generally speaking, the white population of Southern Rhodesia does not appreciate the value of wild life to the same extent as they do in East Africa. Why this is so is hard to say. Perhaps one reason is that the Europeans have never had the opportunity of seeing vast herds of game ranging the plains as can still be seen in Kenya and Tanganyika. The country in Rhodesia does not lend itself to such landscape, for the uncultivated areas are mostly bush and there are few plains bordered by mountains as there are further north. Be that as it may, the wild life is hard put to it to survive and there is even no game department to preserve where suitable, and strictly licence and control elsewhere. There are, however, some enthusiasts and the local Press gave a great deal of publicity recently to a schoolboy who advocated setting aside an area in the Zambesi valley as a game reserve. This boy had many supporters and it is hoped that his proposal will become more than an idea, but it is a regrettable fact that " mountains have to be moved unless there is money in the thing."

The wild life that remains is roughly concentrated in three areas :-

(1) In the neighbourhood of the Wankie Game Reserve on the western edge of the territory.

(2) In the south towards the Transvaal and Portuguese East Africa border.

(3) In the Zambesi valley in the north.

Turning to these three areas, the situation to-day is briefly as follows :-

In the Wankie Game Reserve area there is still a good deal of game, thanks largely to the existence of the reserve which is so 
efficiently and enthusiastically looked after by Major Davison. There are plenty of kudu, sable, roan, and most of the lesser buck in the Reserve. Buffalo are there and elephant-well, perhaps there are too many. (It is a strange fact that the one animal which is on the increase in most British territory is that great pachyderm-the elephant.) Rhino are few and far betweenparticularly in the Reserve and most of the carnivora are there in moderate numbers. The Reserve is, of course, the focal point or sanctuary for this area and the $\mathrm{S}$. Rhodesians are very proud, and rightly so, of this rival of the Kenya national parks. Hence the game in this area should be reasonably safe for the future.

In the south, towards the Transvaal border, the story is not such a happy one. As the farming community increases, more and more land is required and experiments are being carried out to open up the Sabi valley. Where once game abounded, there is now fear for its future. Already it has been decided that more cattle must be grazed on a very large ranch owned by a company and hunters are invited to go and see what they can shoot.

The sting, however, is in the tail, because in the third areathe Zambesi valley-wholesale destruction, which has been going on for several years, is still continuing.

The government's policy is to eradicate the tsetse fly and I think few will dispute that, in areas which hold the particular species of tsetse fly, Glossina morsitans, unmixed with other species, the destruction of the game is followed by the disappearance of the fly. The systematic wholesale destruction of all game continues if anything on an ever-increasing scale, as the following figures will show. In March this year the Minister of Agriculture was asked various questions in Parliament and the following were his replies :-

(1) The maximum number of natives employed on tsetse fly control operations during any one month of 1951 was 987 including 321 unpaid hunters.

(2) The number of rifles issued to natives was 583 .

(3) Rounds of ammunition issued to natives was 62,474 .

(4) The number of game licences issued during 1951 was 1,724 .

(5) During 1951 permits were issued for ammunition as follows :-

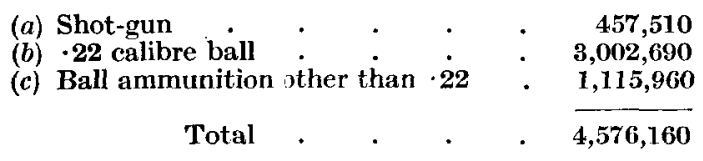


(6) The total recorded (note the word " recorded ") number of wild animals destroyed in Southern Rhodesia in tsetse fly control operations during the four years 1948-1951 was 102,025. The number killed during 1951 was 28,488 .

There is a very long list showing how these totals of 102,025 and 28,488 are compiled, but the following are some of the more interesting items :-

\begin{tabular}{|c|c|c|c|}
\hline \multicolumn{2}{|c|}{ Species. } & $1948-51$ & 1951. \\
\hline Buffalo & & 1,688 & 491 \\
\hline Eland & & 1,186 & 339 \\
\hline Kudu & . & 16,790 & 4,664 \\
\hline Roan & & 861 & 218 \\
\hline Sable & . & 4,352 & 1,120 \\
\hline Impala & • & 9,901 & 2,607 \\
\hline Reedbuck & . & 2,872 & 788 \\
\hline Bushbuck & . & 7,480 & 2,039 \\
\hline Duiker . & . & 27,558 & 8,413 \\
\hline
\end{tabular}

It will be noticed that in each case the figures for 1951 show an increase over the average per year for the three previous years-and that is after three years of destruction! It is indeed tragic that so many of the two most beautiful African antelopes - the kudu and the sable, should have been slaughtered in such numbers-over 16,000 kudu and 4,000 sable in four years. Rhodesia is the home of these antelope and nowhere else do they exist in such numbers. It is difficult to visualize 27,000 duikerthat has been the destruction since 1948 , or even nearly 10,000 impala.

In April this year, I motored from Salisbury to the Zambesi escarpment-some $\mathbf{2 5 0}$ miles. The only wild life I saw, apart from a few doves, was one chameleon which I nearly ran over on the road. Such is the wild life situation in Southern Rhodesia to-day.

This is the old, old story that agriculture and game do not mix well together and one must give way. In a rapidly expanding country the authorities must do all they can to assist agriculture in one form or other. There are, however, large areas where the country is quite unsuitable-unpalatable and difficult of access, at any rate at present, for profitable habitation and it is in these areas that, with due regard to the requirements of the natives, national parks or at any rate game reserves should be established. The Wild Life Protection Society of Rhodesia is doing all it can to rouse public opinion but it has a very uphill task before it. 